\title{
Supporting Freshman Design with an Extracurricular Resource
}

\author{
Asma Idries, North Carolina State University \\ Akira Angel Romero-Berube, North Carolina State University
}

Akira Romero-Berube attended NC State University for her Bachelor's degree in Biological Engineering. She has held a position for five years working as a student with The Engineering Place, a preK-College Engineering education outreach program. Her experience at NC State has left her with a love for the theoretical, technical, and educational facets of engineering and she hopes to pursue a master's or $\mathrm{PhD}$ in engineering education so she can pass on that enthusiasm to others.

\section{Miss Rachel Lee Tilly, North Carolina State University}

Rachel will be receiving my B.S. in Chemical Engineering from NC State come May 2019. She is heavily involved with the Goodnight Scholars program as well as the engineering education outreach efforts by the Engineering Place and its partners. She believes it is important to get future generations excited about STEM in any way, shape or form. Developing a passion for something at a young age can be a powerful tool for success in the future. Teaching kids helps remind Rachel why she fell in love with engineering in the first place.

\section{Dr. Laura Bottomley, North Carolina State University}

Dr. Laura Bottomley, Teaching Associate Professor of Electrical Engineering and Elementary Education, is also the Director of Women in Engineering and The Engineering Place at NC State University. She has been working in the field of engineering education for over 20 years. She is dedicated to conveying the joint messages that engineering is a set of fields that can use all types of minds and every person needs to be literate in engineering and technology. She is an ASEE and IEEE Fellow and PAESMEM awardee.

\section{Ms. Raegan Santana Reeves, North Carolina State University}

I am currently a student at North Carolina State University, as well as a Goodnight Scholar Class of 2020. I am majoring in chemical engineering and would like to work with renewable energy, focusing on alternate resources or more efficient forms of oil.

\section{Mr. Miles Xavier Davis}




\title{
Supporting First-Year Students with an Extracurricular Resource-Complete Evidence-based Practice
}

\begin{abstract}
This study aims to assess the impact of an extracurricular student resource on a design based first-year engineering project experience. The extracurricular resource is referred to as the "resource room" and serves as the material headquarters for the College of Engineering outreach programs at NC State University. The room provides tools, materials, workspace, and mentorship to first-year engineering students for the First-year Engineering Design Day (FEDD) projects. The purpose of this study is to determine the general student perception of this classroom-unaffiliated resource on students' project experience and understanding of the Engineering Design Process. The study has completed its third year of data acquisition, which tracks information on the types of materials most often utilized by students and an estimate of the number of students utilizing the resource room. The interaction between students and this resource has mainly been tracked and gathered through online forms. A new survey, added to the data collection process this year, allowed a quantitative analysis regarding the number of students reached and provided data on how the students feel their learning was impacted. The study overall suggests that collaboration centered extra-curricular resources can improve the project experience for first-year engineering students.
\end{abstract}

Background and Motivation

First-year engineering education and its impact on student retention, culture, and experience is an important topic to current educators trying to improve university level engineering education. Persistence in an engineering program is directly related to the first-year experience [1]. The first-year curriculum and surrounding environment are essential components to providing students with points of both learning and discovery that will ultimately impact their decision to stay within their chosen path [1]. Although the engineering path may not be the best path for every student, there is a serious concern over talented students leaving engineering programs for other majors. In 2015, it was recognized that "most attrition from engineering occurs at the end of the first year, but attrition in the second year is still significant” [2, pg.1].

Some of the negative issues surrounding the typical first-year experience include strictly defined degree paths with rigorous coursework, lack of communication skills or not asking for enough help on the part of the student, lack of a sense of belonging on the part of the student, and professors with no recent training to new and sensitive issues affecting today's student population $[1,7]$. All of these issues add up to a great need to engage students on a personal level [1,7]. A welcoming culture in engineering and across colleges is key to the retention of students, particularly those from underrepresented groups. With the culture of society at large, and engineering in particular, constantly evolving, it is beneficial to understand how undergraduate 
engineers relate to each other and their environment in order to facilitate a culture promoting student success. This ty is complicated by the changing professional identity of today's engineer, as disciplines expand and evolve [3]. Many factors play into the "identity" of a student. Those factors that come from the classroom are easier to quantify than those associated with extracurricular resources. At the college of engineering used in this study, information has been collected on the perceived impact of a current extracurricular resource known as the "resource room". This resource is available to all first year students as an adjunct to the semester design project required by their first semester engineering class.

The resource room supports the college of engineering class projects, mainly the firstyear design projects, as well as providing material supply for K-12 engineering education outreach efforts of the College through The Engineering Place at NC State University. The resource room is staffed and managed by a diverse group of students hired by the Women and Minorities in Engineering Program and represent a diverse array of student backgrounds, genders and ethnicities. This group not only helps to address the needs of first-year engineering students, but also helps with engineering focused activities for the College, networks with K-12 teachers, creates a wide variety of engineering centered lesson plans, and gives tours to visiting $\mathrm{K}-12$ schools from across the state. The resource is classroom-unaffiliated, meaning it was not created for the purpose of supporting the first-year project and is independent of the College of Engineering curriculum. The formal support provided to first-year projects was implemented years after the program's inception and arose out of a desire to help students thrive in their firstyear, not as a demand of the current curriculum.

This resource is a combination of a peer-led learning and leadership program and the traditional makerspace concept. The resource room creates space for students to receive individualized attention and guidance from three sources: first-year peer interaction, matriculated college of engineering student peer interaction, and first-year engineering professor guidance and mentorship. The first-year engineering program at the university requires all FYE students to take the Introduction to Engineering and Problem Solving course and complete the First-Year Engineering Design (FEDD) project. This semester long project is required for each first-year engineering student, usually in teams of four.

In fall 2018, 1,371 students were enrolled in the first year engineering program. Students were assigned to teams and given a problem, then asked to design a solution that they create and display at the end of the semester. One of the resources made available to the students was the resource room and associated workspace room, each of which comprises approximately 1000 square feet—quite a small space. One of the benefits of using the provided workspace attached to the resource room was the ability to consult student staff for material options and general concept questions. Power tools were also provided under supervision from trained staff for use in the work room. Other tools could be checked out for use elsewhere. Most importantly, the projects were completed in a safe environment, ultimately contributing to the well-being of the freshman engineering students and the success of their projects. 
The resource room also fits the broad definition of a makerspace [5]. It is through this space that the resource room staff is seeking to promote a collaborative work environment with access to tools and resources not otherwise found at the university. This resource, efficiently set up in about 1100 square feet of floor space, has become a critical component of traditional first-year design projects at the College of Engineering. One of the key differences between the resource room and a more traditional makerspace is the materials and tools available. The materials and tools are free of charge to the student since they are returned, if possible, at the end of the semester. A wide variety of hand tools includes all types of screwdrivers, wrenches, cutters, saws, etc. Some hand held power tools are available as well. Soldering irons, sewing machines, and Dremels are the most complex tools available. Notably absent are 3D printers, laser cutters and other "newer" tools found in other makerspaces on campus. Supplies include paint, glues, cardboard, sheet metal, balsa wood, scrap wood, plastics, electronic components (including simple discrete processors and integrated circuits), simple motors and Arduinos. A yearly tools workshop is held to teach students basic tool use. The focus of the design project, however, is on the actual iterative engineering process, rather than learning how to use more complex tools or materials. This levels the playing field for students who may not have had previous making experience.

The resource room has become a critical component of first-year engineering design projects at the university. These projects serve as experiential learning for first-year engineering students, giving them a shared experience and introducing students to hands-on engineering. The resource room was not set up solely for this purpose, but, because of demand, adapted to provide student access to a versatile workspace. The nature of the casual interface between students and the resource room staff, who serve as experts and consultants on the design projects, is hypothesized to have many positive impacts on the engineering identity of the students who take advantage of the resource.

Because a positive first-year engineering experience is very important in preventing attrition from the engineering program, research was undertaken to examine the ways in which the resource room might contribute to the desired outcome. This research study addresses the following research questions: What is the effect of a classroom-unaffiliated resource, specifically the resource room, on the first-year project experience? How did using this resource impact innovation, teamwork, project completion, and engineering design process application throughout the first-year semester project? The results of this study are expected to inform the continued operation of the resource room, as well as more advanced research on engineering student identity formation.

Introduction

As first-year students enter into a new college curriculum, there can be a minefield of uncertainties, stresses, and barriers. Transitioning into the college environment holds numerous 
challenges, especially within engineering and other STEM degrees. One of the missions of the resource room is to help first-year engineering students learn and thrive within the College of Engineering. Providing space and resources for these new students is an important part of the resource room's purpose. The resource room is located within an academic building on the main campus of the university. The location of the resource room makes it an easily accessible resource for many of the first-year engineers who live and study on campus.

When students are accepted into the NC State College of Engineering, one of their initial classes during their first fall semester is E 101: Introduction to Engineering and Problem Solving. In this course, students are given a semester long team assignment in which they design various projects which are later presented on a design day in late November. Many of these E101 class sections are actually within the same academic building as the resource room. Students often find it convenient to stop by the resource room before or after class to work on their projects throughout the semester with their project teams.

The resource room has become vital to supporting students through the project process as they become familiar with the design cycle and what it means to be an engineer. Through an inviting work space, mentoring from the resource room staff, and the various tools and materials available, the resource room has served first-year engineering students for multiple years. It provides multiple layers of support for students as they develop their projects. The resources within the room range from simple rolls of tape and popsicle sticks to power drills and wood. During the fall and spring semesters, the resource room is staffed by 3-6 students for 25-35 hours a week, typically in the 9am - 5pm window. There are also additional evening/weekend hours staffed up to 2 weeks prior to the first-year project due date, totaling about 10 hours a week in the 7pm - 9pm time frame on weekdays and during the day Saturday and Sunday. The resource room can accommodate around ten people comfortably, and the attached workspace can accommodate four groups at maximum, which can be as many as 24 students.

The resource room staff members are often students further along in their engineering degrees and are there to serve as a support system for the first-years. Staff help first-year students check out various materials and teach and advise them on their projects along the way. The aim of all of these resources is to provide an inclusive and supportive work environment to enable first-year students to really dig into the engineering design cycle and practice thinking critically. Through providing this external and free resource, the College hopes to enable engineering students to more easily overcome the challenges they oftentimes face their first semester and to be more comfortable with exploring the idea of what it means to be an engineer.

This study assesses first-year students’ perceptions of their learning experience after interacting with the resource room. Results include student opinions on improved teamwork, creativity, and project execution. Additionally, the data includes a student view of the resource room itself, including its purpose, the materials available, and helpfulness of the student staff. General demographic information was included to compare against the overall population of the 
first-year engineering students to show who is being reached through these efforts. The collected data can serve as a baseline of improvement of this resource and an example for implementation of this type of resource elsewhere. In addition, the study may provide a launch point for more sophisticated research on student identity formation.

\section{Methods}

Quantitative data were collected to measure material use, resource quality, and student perception of how the resource room affected their learning experience. Material use was tracked through a check-out process. Students filled out a form that was transferred to a google sheet to keep a log for each group of materials checked out and returned. Student perception and resource quality was measured through a survey.

\section{Participants}

After FEDD (First-Year Engineering Design Day) was completed in late November, a Google form survey was sent out to all the first-year students from the last two academic years by email. Email was used to maximize the number of responses from the thousands of students who completed a FEDD project. The target population for the survey was all first-year engineering students from Fall 2017 and Fall 2018, which amounts to 2,865 students, since they all must participate in FEDD. Of these students, 46.5\% (1,332) visited the resource room. From this target population, 19\% (248) responded to the survey. This results in a response rate of $8.6 \%$ from the overall population of all first and second year students. The first set of questions in the survey asked for demographic information including sex and race/ethnicity. Table 1 contains both the demographic information for the college of engineering first-year classes of 2017 and 2018 and the survey participants. Figure 1 compares the sex distribution of the survey respondents to the college of engineering first-year class, and Figure 2 shows the comparison of race/ethnicity. 
Table 1: Demographics of Survey Respondents

\begin{tabular}{|l|c|c|c|c|}
\hline & \multicolumn{2}{|c|}{ Total FYE Students } & \multicolumn{2}{c|}{ Survey Respondents } \\
\hline Total Students & \multicolumn{2}{|c|}{2,865} & 106 & $39 \%$ \\
\hline Female & 830 & $29 \%$ & 166 & $61 \%$ \\
\hline Male & 2035 & $71 \%$ & 5 & $1.8 \%$ \\
\hline Native American & 27 & $0.94 \%$ & 13 & $4.8 \%$ \\
\hline African American & 120 & $4.2 \%$ & 18 & $6.6 \%$ \\
\hline Hispanic & 131 & $4.6 \%$ & 24 & $8.8 \%$ \\
\hline Asian & 375 & $13.1 \%$ & 209 & $77 \%$ \\
\hline White/ Caucasian & 1959 & $68 \%$ & 3 & $1.0 \%$ \\
\hline $\begin{array}{l}\text { Prefer not to } \\
\text { answer or } \\
\text { Unknown }\end{array}$ & 66 & $2.3 \%$ & & \\
\hline
\end{tabular}

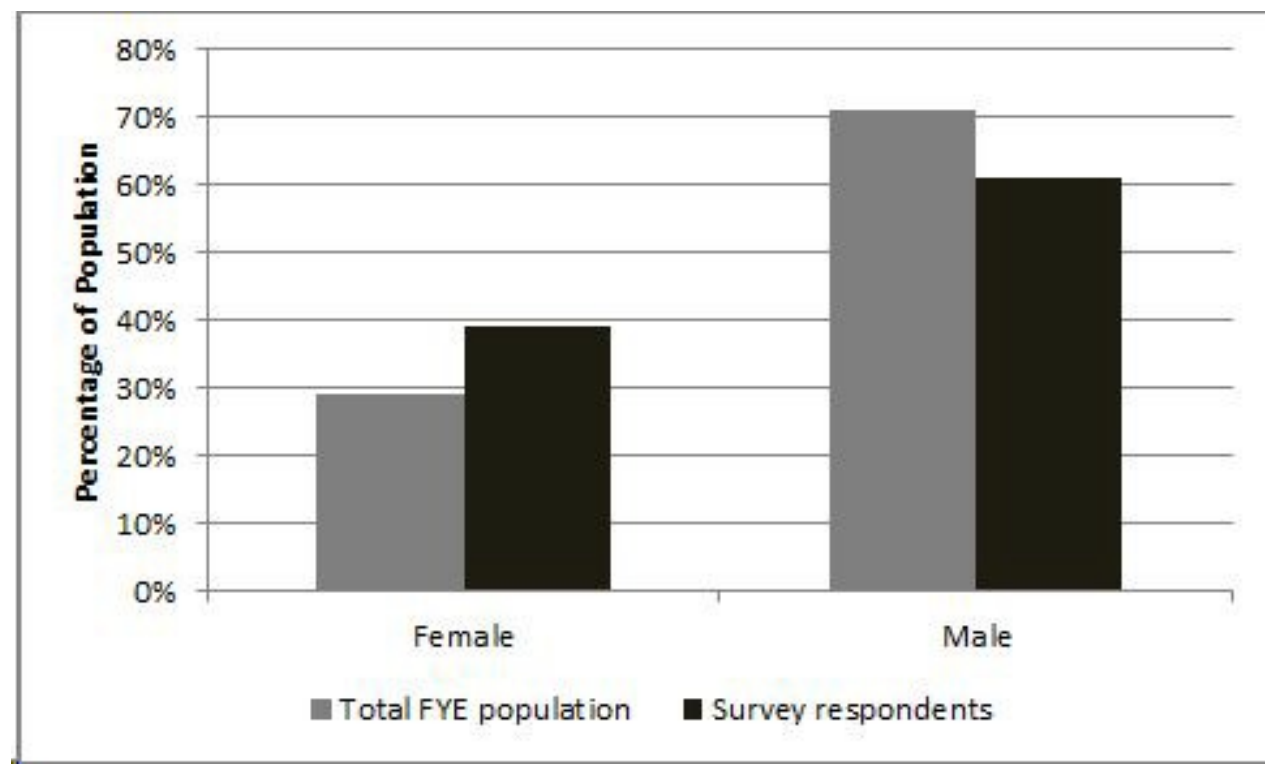

Figure 1: Comparison of Sex distribution of Sample to First-Year College of Engineering 


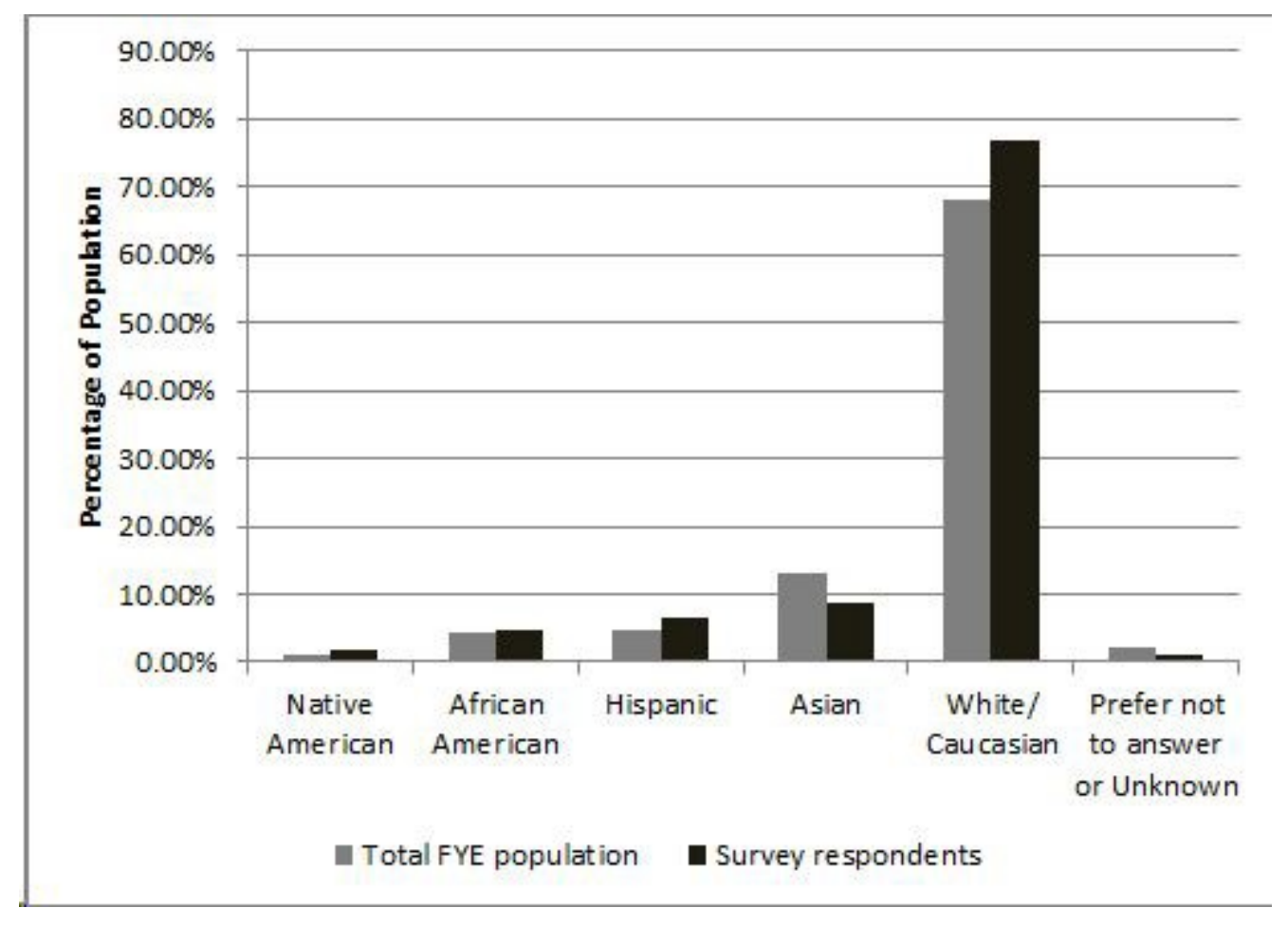

Figure 2: Comparison of Race/Ethnicity of Survey Sample to First-Year Engineering Race Demographics

\section{Measures}

The survey asked questions about the use of resource room and the impact of the resource room on their learning experience, particularly to gauge the usefulness and impact of the space. The first set of questions contained questions about sex, race/ethnicity, how the students heard of the resource room, and their reason to visit. The next set asked the students to measure different aspects of the services at the resource room from unsatisfactory to outstanding. The third section was a series of statements about the learning impact of using the resource room, and students were asked to select how closely they agreed or disagreed with each statement. Data obtained from the survey was evaluated on a 1-5 scale, then used to quantify how much the students felt affected by the resource room. Table 2 contains the survey questions and response type of each question.

Table 2: Survey

Questions

Section 1: Sample Information

\begin{tabular}{|l|l|}
\hline \multicolumn{1}{|c|}{ Question } & \multicolumn{1}{c|}{ Response Type } \\
\hline Sex & Multiple Choice \\
\hline Race/Ethnicity & Multiple Choice \\
\hline $\begin{array}{l}\text { Did you visit the resource room with the purpose of seeking project materials, tools, } \\
\text { project assistance, or work space ? Choose all that apply. }\end{array}$ & Multiple Choice \\
\hline
\end{tabular}




\section{Section 2: Service Rating}

\begin{tabular}{|l|l|}
\hline \multicolumn{1}{|c|}{ Question } & Response Type \\
\hline Rate the availability of materials in the resource room. & Scale of 1-5 \\
\hline Rate the variety of materials in the resource room. & Scale of 1-5 \\
\hline Rate the work-space provided. & Scale of 1-5 \\
\hline Rate access to tools in the resource room. & Scale of 1-5 \\
\hline How would you rate the variety of tools in the resource room. & Scale of 1-5 \\
\hline The student staff answered my questions well. & $\begin{array}{l}\text { Scale } 1-5 \\
1=\text { Strongly Disagree } \\
5=\text { Strongly Agree }\end{array}$ \\
\hline
\end{tabular}

Section 3: Impact on Project Experience

\begin{tabular}{|l|l|}
\hline \multicolumn{1}{|c|}{ Question } & \multicolumn{1}{c|}{ Response Type } \\
\hline This resource was helpful in completing my project & $\begin{array}{l}\text { Scale 1-5 } \\
\text { = Strongly Disagree } \\
5=\text { Strongly Agree }\end{array}$ \\
\hline I felt more confident going into my project knowing about this resource & $\begin{array}{l}\text { Scale 1-5 } \\
1=\text { Strongly Disagree } \\
5=\text { Strongly Agree }\end{array}$ \\
\hline This resource helped me stress less about my project & $\begin{array}{l}\text { Scale 1-5 } \\
\text { = Strongly Disagree } \\
5=\text { Strongly Agree }\end{array}$ \\
\hline This resource helped me better understand the engineering design process. & $\begin{array}{l}\text { Scale 1-5 } \\
1=\text { Strongly Disagree } \\
5=\text { Strongly Agree }\end{array}$ \\
\hline This resource helped me be more creative or innovative with my project. & $\begin{array}{l}\text { Scale 1-5 } \\
\text { = Strongly Disagree } \\
5=\text { Strongly Agree }\end{array}$ \\
\hline This resource helped my team work together better. & $\begin{array}{l}\text { Scale 1-5 } \\
1=\text { Strongly Disagree } \\
5=\text { Strongly Agree }\end{array}$ \\
\hline This resource made executing my project plan easier. & $\begin{array}{l}\text { Scale 1-5 } \\
1=\text { Strongly Disagree } \\
5=\text { Strongly Agree }\end{array}$ \\
\hline & $\begin{array}{l}\text { Scale 1-5 } \\
\text { I Strongly Disagree } \\
5=\text { Strongly Agree }\end{array}$ \\
\hline
\end{tabular}




\section{Procedures}

Materials taken from the resource room were tracked through a google form. The students were given access to the google form via a QR code and shortened URL posted outside of the resource room. The materials tracked fell into two categories, "Returnable" and

"Non-Returnable". Returnable materials are objects that when disassembled from the project are close to the original condition in which the student checked them out, or objects that can be safely reused. Non-Returnable items are broken items, cardboard, or other scrap and building materials from the "re-use" bins. This distinction further benefited cost analysis, as most returnable items were in fact returned to the resource room and could be counted as "one-time” costs. Non-returnable materials are required to be repurchased.

As students enter the resource room, they identify materials they need and fill out the google form. A staff member then signs off to indicate approval, and the students then take the items or stay and use the resource room as a workspace for their project. Power tools are not checked out to students and are strictly supervised by staff when in use.

Results

To determine the quality of this extracurricular resource in terms of material inventory and peer-led assistance, survey questions were included assessing these aspects of the resource room. Table 3 shows the average ratings of the different aspects of the resource room. These questions asked for a rating from 1-5, with 1 meaning unsatisfactory and 5 meaning outstanding.

Table 3: Survey Questions Section 2 - Average Responses to Resource Room Service Quality

\begin{tabular}{|l|c|c|c|}
\hline \multicolumn{1}{|c|}{ Statement } & $\begin{array}{c}\text { Number of } \\
\text { Responses }\end{array}$ & Average Rating & Median Rating \\
\hline $\begin{array}{l}\text { Rate the availability of } \\
\text { materials in the } \\
\text { resource room. }\end{array}$ & 148 & $4.1 / 5$ & $4.2 / 5$ \\
\hline $\begin{array}{l}\text { Rate the variety of the } \\
\text { materials in the } \\
\text { resource room. }\end{array}$ & 148 & $4.2 / 5$ & $4.2 / 5$ \\
\hline
\end{tabular}




\begin{tabular}{|l|c|c|c|}
\hline $\begin{array}{l}\text { Rate the work-space } \\
\text { provided. }\end{array}$ & 145 & $3.4 / 5$ & $3.3 / 4$ \\
\hline $\begin{array}{l}\text { Rate the access to tools } \\
\text { in the resource room. }\end{array}$ & 145 & $3.9 / 5$ & $4.2 / 5$ \\
\hline $\begin{array}{l}\text { Rate the variety of tools } \\
\text { in the resource room. }\end{array}$ & 144 & $3.8 / 5$ & $4.2 / 5$ \\
\hline & 144 & $3.9 / 5$ & \\
\hline $\begin{array}{l}\text { The student staff } \\
\text { answered my questions } \\
\text { well. }\end{array}$ & 146 & $3.8 / 5$ & $4 / 5$ \\
\hline Overall Average & & & \\
\hline
\end{tabular}

In order to assess the interest in continuing to provide this resource among the freshman engineering class and set up a framework for assessing the impact of the resource room on the first-year project experience, information on the use of the room was obtained. A key tool for attaining the data was an online form that each student was required to complete when checking out any material from the resource room. The total number of students that visited the resource room was obtained from this tool and amounted to 1332 students, which represents $46.5 \%$ of the total first-year engineering classes in the two years studied here.

Figure 3 shows the percentage of students that mentioned materials, tools, assistance, or workspace as a part of their response. These are the students' initial reasons for visiting the resource room, and this purpose could have changed after the first visit and introduction to the other resources available, such as the work space and peer-led assistance. A majority of the sample, $48 \%$ (127), included materials as the primary reason for visiting the resource room. The most frequently borrowed materials were also observed data collected, with battery packs, hot glue guns, motors, wire, and wood being the most checked-out materials. The least common initial purpose for visiting the resource room was to seek assistance, with $12 \%$ (32) of the sample indicating this purpose. 


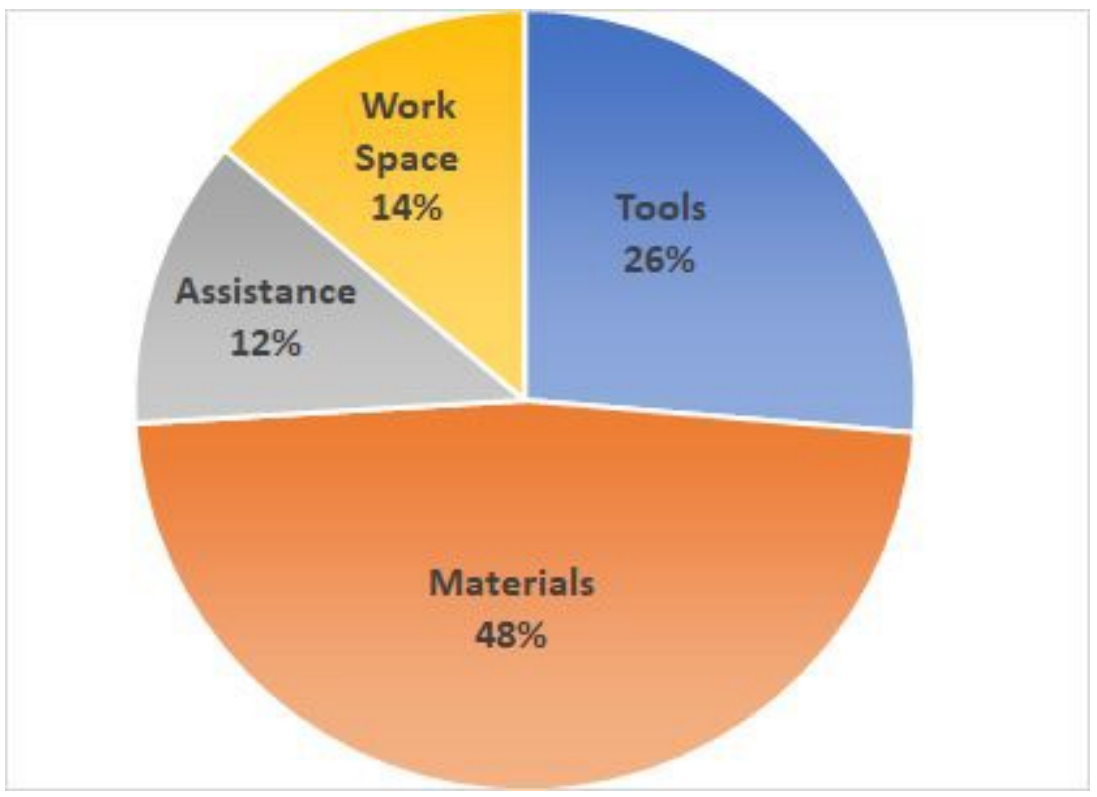

Figure 3: Initial Reason for Visiting the Resource Room

To assess the effect of the resource room on the first-year project experience, the survey data were used to answer questions on innovation, teamwork, project completion ability, and engineering design process application impacts. These questions were to be answered using a Likert scale from 1 to 5, with 1 indicating strongly disagree and 5 indicating strongly agree. A table of the responses and average rating for each question is provided as Table 4.

The improved ability to work as a team was also assessed. The work-space is typically the location of collaborative teamwork within the resource room, and group members often meet up at the resource room when looking for resources. In response to whether the resource room enabled teams to work together better, the average rating was above the median (3.4/5, shown in Table 4). As discussed earlier, the work-space itself was given an average quality rating of $3.4 / 5$, which could be related to the teamwork ability rating since the work-space is a big facilitator of this aspect.

Table 4: Survey Questions Section 3 - Average Responses to Impact on Project Experience

\begin{tabular}{|l|c|c|c|}
\hline \multicolumn{1}{|c|}{ Statement } & Number of Responses & Average Rating & $\begin{array}{c}\text { Median } \\
\text { Rating }\end{array}$ \\
\hline $\begin{array}{l}\text { This resource was helpful in completing my } \\
\text { project }\end{array}$ & 147 & $4.1 / 5$ & $5 / 5$ \\
\hline $\begin{array}{l}\text { I felt more confident going into my project } \\
\text { knowing about this resource }\end{array}$ & 144 & $3.9 / 5$ & $4 / 5$ \\
\hline
\end{tabular}




\begin{tabular}{|l|c|c|c|}
\hline $\begin{array}{l}\text { This resource helped me stress less about } \\
\text { my project }\end{array}$ & 144 & $3.9 / 5$ & $4.2 / 5$ \\
\hline $\begin{array}{l}\text { This resource helped me better understand } \\
\text { the engineering design process. }\end{array}$ & 143 & $3.2 / 5$ & $3.3 / 5$ \\
\hline $\begin{array}{l}\text { This resource helped me be more creative } \\
\text { or innovative with my project. }\end{array}$ & 144 & $3.6 / 5$ & $4 / 5$ \\
\hline $\begin{array}{l}\text { This resource helped my team work } \\
\text { together better. }\end{array}$ & 144 & $3.4 / 5$ & $4 / 5$ \\
\hline $\begin{array}{l}\text { This resource made executing my project } \\
\text { plan easier. }\end{array}$ & 144 & $4.1 / 5$ & $4.2 / 5$ \\
\hline $\begin{array}{l}\text { I think this resource should be available } \\
\text { again next year to first-year students }\end{array}$ & 147 & $4.7 / 5$ & $5 / 5$ \\
\hline Overall & $\mathrm{N}=144$ & $4.4 / 5$ & $4.2 / 5$ \\
\hline
\end{tabular}

General data was collected on sex and race with the surveys to compare the target population of the survey with the corresponding overall college of engineering demographics. This data is represented in Table 1 in the methods section. This gives a baseline description for student's backgrounds and a measure of how they compare to their peers on two key identifying factors. Figure 4 shows the percentage of the student visitors of the resource room to the total FYE students by ethnicity. The number of student visitors of the resource room is given by $n$.

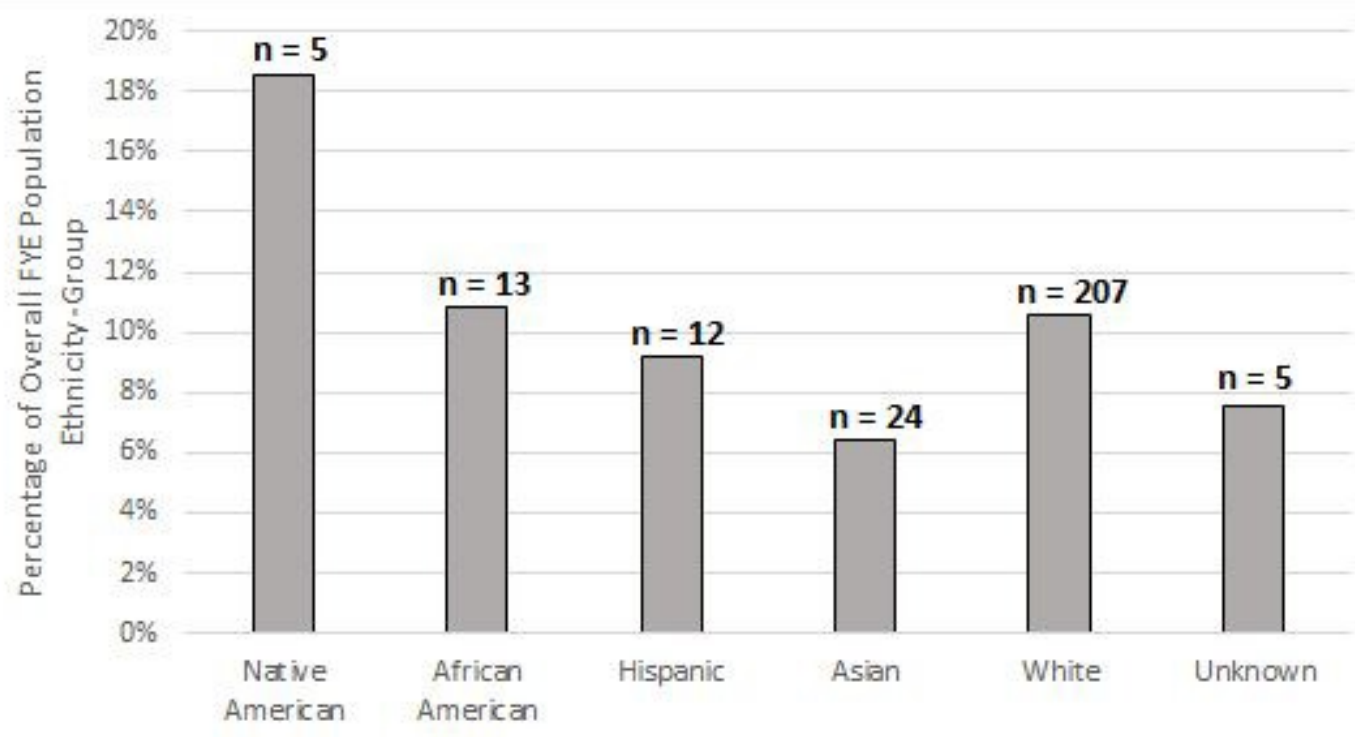

Ethnicity

Figure 4: Percentage of Resource Room Student Visits to First-Year College of Engineering Ethnicities 
Discussion

In general, the survey results showed that the resource room had a positive impact on the FEDD project experience. The average rating in response to the general helpfulness of the resource room is $4.1 / 5$, and the average rating for the increased ease of project execution from visiting the resource room was $4.1 / 5$, as seen in Table 2 . The helpfulness of and need for the resource room are again reinforced with the average rating of the statement "I think this resource should be available again next year" being 4.7/5. This resource also allowed students to mitigate some stress related to completing the project, with the average rating of this response being 3.9/5. The ability to gain feedback from students on the availability of the resource room is an important, since this experience could affect attrition from the engineering program [2].

The work-space provided by the resource room was also given a slightly above median rating of $3.4 / 5$. The rating for the student staff's ability to answer questions from the students was also given a high rating, with the average being 3.9/5. The workspace carried the lowest rating, which was most likely due to size constraints. A few times during the semester the workspace was completely full with a short wait time to enter. The survey results indicate the high quality of the resource room as a material and tool resource with high ratings for the availability and variety of the materials and tools in the resource room. These responses help identify the resource room as a quality outside resource for tools and materials, with room for improvement to the physical space. The resource room usage suggests interest among first-year engineering students for other resources beyond the classroom. With the wide range of resources that is provided by the resource room, data collected through the survey included a question about the initial purpose of visiting the resource room. This question gave the students the option to choose multiple responses. This variety of the initial reasons indicated by the sample demonstrates the variety of applications of the resource room. In terms of peer-led assistance, peer-led learning among students has been shown to improve student understanding [4]. This understanding is a desirable feature to provide with extracurricular resources.

Frequent use of the materials provided in the resource room demonstrates a need for access for basic, as opposed to more sophisticated materials, throughout the project process. There has been a recent upward trend in universities to include makerspaces and similar resources on their campuses because of this need, since classroom resources typically do not have more varied and interesting materials for project use. Overall it is observed here that students in the engineering program are in need of various types of materials that are not provided in the classroom and will make use of the access to these resources. 
An important goal of the resource room is to foster innovation among students with their project designs by providing a wide variety of materials. Many students initially visit the resource room without a clear idea of the potential direction of their project, and viewing the variety of materials in the room typically provides the impetus for brainstorming design ideas.

The survey results indicated that the resource room aided the creativity mindset of the majority of the sample. The average rating to the statement "The resource room helped me be more creative or innovative with my project” was 3.6/5. Enabling a more creative approach to project designs has been a common goal among the implementation of similar resources in universities, which is a primary reason for possessing a good inventory of materials and tools for brainstorming and prototyping project ideas [5].

An improved understanding of the engineering design process was a potential impact from using this extracurricular resource and was also assessed through student surveys. The work done in the resource room by the students typically ranges across the engineering design process, from initial brainstorming to improving their designs. However, the correlation between the work done in the resource room and the engineering design process is made in more of an implied, rather than explicit, fashion. The resource room does display the engineering design process poster, but it is not typically emphasized. The increased understanding of the engineering design process received an average rating of 3.2/5, as seen in Table 4 . This leaves the possibility that a more emphasized connection between the work done in the room and the engineering design process can help the resource do more to further improve the understanding of this concept.

Another aspect of the resource room that was assessed was the visitation differences regarding different sexes and ethnicities. Attrition rates for females and minorities are generally higher than Caucasian students, and according to a study in the New York City College of Technology, minority students typically benefit greatly from peer-led resources [4]. The resource room is a student staffed resource, therefore demographic data were collected in order to view the differences in the types of students that visited the resource room and to analyze the use of this type of resource among minorities. The sex information from the survey compared to the total college of engineering first-year class is shown in Figure 1, and the ethnicity demographic information is shown in Figure 2. The majority of the sample were Caucasian, with 83\% (207 respondents) choosing this response. In comparison to the entire first-year engineering class demographics, women were over represented as visitors to the resource room, as seen in Figure

1. In terms of ethnicity, the distribution of ethnicities among the first-year College of Engineering students was similar to the percentages among those that visited the resource room. Figure 4 shows the students of a particular ethnicity that visited the resource room compared to the percentage of that ethnicity in the total first-year college 
of engineering class. 19\% (5 students) of the Native Americans in the college of engineering visited the resource room. 11\% (13 students) of African American students in the college of engineering first-year class visited the resource room. While the causes of these results cannot be determined from data collected through this study, the data may be related to the literature findings of peer-led resources having a valuable impact on minority students [4]. Future research into engineering identity establishment will examine this more closely.

\section{Conclusion}

This study aimed to assess the effect of an extracurricular resource on the project experience of first-year engineering students. The resource room is a unique resource to the College of Engineering in that it provides a wide variety of materials and tools, an area for project work, and peer-led assistance. The aspects that were assessed involved project performance, innovation, teamwork, and understanding of the engineering design process. Quantitative data were collected to assess the utilization of this resource, and its effect on the projects. The survey data indicated that the resource room generally had a positive effect on the project experience, including positive effects on the creativity and teamwork throughout the project experience. This assessment suggest that the needs of today's student includes providing the tools and environment needed to foster a creative and positive first-year project experience with an extracurricular resource of this nature.

\section{Future Work}

This study was the first that obtained student data from surveys after FEDD, and future surveys can aid significantly in further understanding the needs of the students and the role of resources like the resource room in forming engineering identity. To more directly measure the impact on students of the available resources, a pre-post test could be used to measure change in students' knowledge of key concepts, such as the engineering process. By comparing change from before starting the FEDD project and after completion and comparing those who used the resource room to those who did not, the research would more thoroughly assess impact on learning beyond student perception.

To extend the efforts of this study, one area for further discussion involves the direct effects of using these types of resources on the attrition of engineering students. As discussed earlier, attrition is a common issue within engineering programs, especially for members of underrepresented groups. Another important topic for further investigation is the effect that the resource has on students with different demographics. While the study does address a few demographic aspects, enough data were not collected to make an inference of the effect on particular groups. This is an important point as there is a global push for diversity in the workplace, especially in 
engineering. Providing an Effective learning environment for students of all backgrounds is key to this effort. Measuring the additional effects of these extracurricular resources can incline more universities to include them on their campuses.

\section{References}

[1] K. Meyers et al, "AC 2008-1226: PERSPECTIVES ON FIRST YEAR ENGINEERING EDUCATION," Age, vol. 13, pp. 1, 2008.

[2] A. Dreyfuss et al, "Getting past the first year: Retaining engineering majors," in Frontiers in Education Conference (FIE), 2015 IEEE, 2015, .

[3] E. Godfrey and L. Parker, "Mapping the cultural landscape in engineering education," Journal of Engineering Education, vol. 99, (1), pp. 5-22, 2010.

[4] J. Liou-Mark et al, "The peer-led team learning leadership program for first year minority science, technology, engineering, and mathematics students," Journal of Peer Learning, vol.

11, (1), pp. 65-75, 2018.

[5] M. M. Hynes and W. J. Hynes, "If you build it, will they come? Student preferences for Makerspace environments in higher education," International Journal of Technology and Design Education, vol. 28, (3), pp. 867-883, 2018.

[6] C. R. Forest et al, "The Invention Studio: A University Maker Space and Culture." Advances in Engineering Education, vol. 4, (2), pp. n2, 2014.

[7] Anne-Barrie Hunter, Heather Thiry, Dana Holland, Raquel Harper, Elaine Seymour, "Talking about Leaving Revisited - A Multi-component Research Study Exploring Factors Influencing Undergraduate Switching from STEM Majors:Preliminary Results from the Persistence Study,” APLU Annual meeting, November 2018, http://www.aplu.org/projects-and-initiatives/stem-education/science-and-mathematics-teachingimperative/smti-conferences-meetings/SMTI\%202016\%20National\%20Conference/HunterPoster.pdf, retrieved March 2019. 